Klyuchnyk Alyona, Doctor of Economic Sciences, Professor, Head of Public Management and Administration, International Economics Department, Mykolayiv National Agrarian University, Mykolayiv, Ukraine

ORCID ID: 0000-0001-6012-6666

e-mail: klyuchnikav@mnau.edu.ua

Kormyshkin Yurii, Doctor of Economics, Professor of the Department, Mykolayiv National Agrarian University, Mykolayiv, Ukraine

ORCID ID: 0000-0002-1005-1229

e-mail: kormyshkin@mnau.edu.ua

Husenko Angela, senior lecturer of Public Management and Administration, International Economics Department, Mykolayiv National Agrarian University, Mykolayiv, Ukraine

ORCID ID: 0000-0002-3989-2400

e-mail: gusenko@mnau.edu.ua

Galunets Natalia, teaching assistant of Public Management and Administration, International Economics Department, Mykolayiv National Agrarian University, Mykolayiv, Ukraine

ORCID ID: 0000-0001-7709-9238

e-mail: galunetsni@mnau.edu.ua

\title{
Foreign Practice of Legal Groundwork for State Officials Ethical Conduct
}

Abstract. Foreign countries' practice as for legal groundwork for state officials conduct and public service reforms is considered. Comparative analysis of legal groundwork for state officials conduct of such countries as the USA, Canada, FRG and the UK is given. It is examined that a state official in the USA has to execute duties honestly, fairly, without giving any privileges to certain physical and legal entities. It is specified that effective reputational control is taken by state officials associations in western democracies. Therefore, for instance, there are two such associations in the USA - American Society of Public Administration and International City/County Management Association. In Canada the Commissioner's Office in Ethics and Conflicts of Interests is successfully functioning. That political institution is independent from any political forces and deals with Canadian MPs' conduct monitoring. It is established that the Structure of principal ethical rules for state officials in France is typical for democratic countries. It includes: commitment to laws and instructions; impartiality; commitment to keep secrecy; passiveness in social and political sphere; prohibition of other professional activities; loyalty; honesty. Listed above rules are considered to be foundation for state officials' ethics. On the one hand, the peculiarity of that document is to regulate professional activities ethics for officials, on the other hand, it determines state officials' duties. In accordance with conducted research results, it is revealed that Codes of conduct for state officials are normally adopted to stand against corruption and prevent conflict of interests. It is considered that one of the principal factors to stand against corruption is professional state official ethics. We have made a conclusion that in spite of differences in several countries approaches to state officials organizational culture formation, its goal remains unchangeable - to provide officials' professional activities in the society's interests, to prevent possible abuse of authority and breach of the law. Functioning effectiveness and given practice application in modern Ukraine in present conditions in order to provide effective reforms of state service system are stipulated.

Key words: ethical conduct; state service; practice; legal groundwork; code of ethical conduct.

\section{УдК 32.172}

Ключник А. В., доктор економічних наук, професор, завідувач кафедри публічного управління та адміністрування та міжнародної економіки, Миколаївський національний аграрний університет, м. Миколаїв, Україна

Кормишкін Ю. А., доктор економічних наук, професор кафедри, Миколаївський національний аграрний університет, Миколаїв, Україна

Гусенко А. А., старший викладач кафедри публічного управління та адміністрування та міжнародної економіки, Миколаївський національний аграрний університет, м. Миколаїв, Україна

Галунець Н. І., асистент кафедри публічного управління та адміністрування та міжнародної економіки, Миколаївський національний аграрний університет, м. Миколаїв, Україна 


\section{Зарубіжний досвід правового забезпечення етики поведінки державних службовців}

Анотація. Розглянуто досвід зарубіжних країн щодо правового забезпечення етики поведінки державних службовців та реформування публічної служби. Надається порівняльний аналіз правового забезпечення етики поведінки державного службовия країн: США, Канади, ФРН та Великої Британії. Розглянуто, що державний службовець в США має виконувати свої посадові обов'язки чесно, неупереджено, не надавати будь-яких переваг та не виявляти прихильність до окремих фізичних і юридичних осіб. Визначено, що у західних демократіях ефективний репутаційний контроль здійснюють асоціації державних службовців. Так, наприклад, у США діють дві таких асоціації - Американське товариство державного управління та Міжнародна асоціація управління містами та районами. У Канаді успішно працює офіс Комісара з питань етики та конфлікту інтересів. Ця незалежна від будь-яких політичних сил парламентська інституція проводить моніторинг поведінки канадських парламентарів. Встановлено, що Структура основних етичних правил державних службовців Франції типова для демократичних країн. Вона включає: обов'язок дотримуватися законів та інструкцій; безсторонність (неупередженість); обов'язок конфіденційності; пасивності у суспільному політичному прояві; заборону інших професійних занять; лояльність; чесність. Перелічені правила $\epsilon$ основою етики державних службовців.

Особливість цього документу полягає у тому, що він, з одного боку, регламентує етику професійної діяльності службовців, а з іншого - визначає обов'язки державних службовців. За результати проведеного дослідження, встановлено, що найчастіше Кодекси поведінки державних службовців приймають з метою протидії корупції та запобігання конфлікту інтересів. Вважається, що одним з основних чинників протидії корупції $\epsilon$ професійна етика державного службовця. Зроблено висновок, що попри відмінності у підходах різних країн до формування організаційної культури державних службовців, незмінною є ї̈ мета - забезпечити професійну діяльність службовців в інтересах суспільства, а також запобігти можливим зловживанням владою та порушенням закону. Обгрунтовується ефективність функціонування та використання даного досвіду на теренах сучасної України та в сучасних умовах задля ефективного реформування системи державної служби.

Ключові слова: етична поведінка; державна служба; досвід; правове забезпечення; кодекс етичної поведінки.

Formulation of the problem. The democratization of social and political life in Ukraine, over the last years, carrying out of radical social and economic transformations, local self-government reforming, devolution of power to the regions in the country which is aiming to be completed, have caused new rethinking of legal groundwork as for state service organization and public officials ethical conduct. Taking into consideration the strategic task of Ukraine to enter the EU, one of the challenging issues of the state service system in force, which needs to be currently solved, is considered to be the issue as for the policy management of public officials' professional ethics demands. Thus wise, realization of the importance of ethics and state service cohesion in foreign countries has resulted in approving special statutory enactments as for the issues of public officials ethics in most of those countries. Therewith, we consider the experience of the countries which have managed to be added to the list of twenty least corrupted countries and made certain progress in the management of moral relationship sphere in the state service of their countries as the most worth-while [1].

Analysis of recent research and publications. The problems and praxis of ethics codes realization in the state officials' professional activities reflected in the works of foreign scholars, namely: W. Bruce, H. Benson, T. Cooper, K. Kernagan, B. Kudrytska, K. Lewis, G. Plantn, G. Pope, R. Chandler, R. Chapman and others. Among Ukrainian and Russian scholars this problem was researched by $\begin{array}{lll}\text { V. Bakshtanovskyi, D. Vasyl'yev, T. Vasylevska, } & \text { D. }\end{array}$ P. Drobyshev, O. Konov, O. Obolonskiy. Theoretical analysis as for the given direction was made by M. Rudkevych, M. Nynyuk, N. Nyzhnyk, V. Tsvetkov, N. Shuvalova and others. Regardless, in Ukraine certain rules and regulations as for ethics and state officials' code of conduct ensuring are not quite well developed and require futher scientific research.

Formulation of research goals. The aim of the article is to investigate foreign practice as for the rules and regulations in the sphere of state officials' ethics conduct and to find out solutions how to adapt them into home state officials' practical work. In order to achieve that goal we have defined the following tasks: to research legislative and other statutory instruments in the sphere of state officials' ethics conduct in several countries of the world; to outline the factors and background from foreign experience that would be helpful within the process of preparation and realization of rules and regulations in the sphere of state officials' ethics in Ukraine.

Outline of the main research material. Under current conditions it is of urgent importance to implement state management reforming and making Ukrainian state service closer to the world standards. One of the most significant constituents of the state officials' professional activities is their professional conduct. The list of standard restrictions and prohibition activities for state officials regarding professional ethics is affirmed in the legislative instruments of all developed countries. Those actions are considered to be quite effective and their strict realization shall make a direct impact on the professional level of the officials and people's credibility to the authorities.

Crucial constituent of state service ethics infrastructure, professional conduct core are considered to be state officials' codes of conduct. Code of conduct (moral) is translated from Latin as "a book" - a body of moral rules, requirements, norms those are dictated to be executed. Norms and rules having been awared of and included into the general practice of the majority of the profession are fixed in the codes of conduct. Those norms and rules are considered to be the historical heritage of 
the society and professional environment; requirements and regulations are rationally and morally stipulated but are often broken. The Code of conduct in the system of state service is regarded as a body of professional and ethical values, principles, requirements to the state officials dictated to be executed [2].

According to T. Vasylevska, the codes, in the framework of state service, enable, on the one hand, to regulate managerial and service conditions among authorities, on the other hand, to favor the creation of positive attitude to them and to become the basis for professional group social responsibility formation; for each representative and foundation for social estimation of bureaucracy.

At the same time, the scholar states that a body of ethics regulations are necessary to outline service conduct precise baselines and to make certain samples which explain the conduct in order to improve the level of rationality and morality in the authorities' professional activities. [3].

In G. Pope and K. Kernagan's view, the codes are devoted to advance democracy values and improve the level of trust of the public to the government, assist the trust among power structures and promote the standards of administrative conduct in the state organizations. As for W. Bruce, who asserts that the codes are specified as certain manual for those who enable to make managerial decisions and deal with the situations when certain values could be the subject of the conflict. The value of the codes, in accordance with $\mathrm{H}$. Benson, cannot be measured by only as an effective manual devoted to confine proper and avoid unacceptable conduct. As legal and managerial instrument the codes are to outline the boundaries of the conduct, establish the standards, undertake some functions of control as well.

With that in mind, civil service moral foundation formation in most countries used to start from working out the code of conduct as a statutory document comprising the system of ethical norms, principles and rules those shall be employed by state officials in their professional activities [4]. Those documents are adopted in most countries of Europe, member-states of the British Commonwealth, the USA and other countries [5].

Thus, in our view, the research of the experience of the countries where the statutory regulation of state officials' professional conduct requirements, not only the statement of moral-ethic principles of state officials' work-related conduct, but the mechanism of legislative support of their implementation in order to assist the improvement of home legislative ethical conduct base for state service in Ukraine is appeared to be really significant.

The USA are considered to be the pioneers in that sphere. The first Code of conduct was developed by International Urban Administrators Association (now International City/County Management Association) in 1924. Thirty years later in 1958 Government Service Code of Conduct was adopted in the form of US Congress resolution and was supported by legislative statutory instrument "Public Officials' Standards of Conduct" [3].

However, the development of US state service ethic system, which has its legislative foundation, started not from the Code of conduct but from the US Constitution and principal factors of governmental ethics fixed as its integral part. Freedom, justice, equality are essential state values as norms of democratic co-living of citizens which have affirmed in the struggle for independence.

World practice shows that under certain historically formed conditions, reinforcement of civil service moral values in the legislative acts is stipulated by its successful implementation into life. As a result, the USA remained one step ahead of the others when adopted Law "On Government Conduct" in 1978 in the framework of civil service reforms.

From the late eighties the US state service ethical requirements became the object of the strictest both social and legal control even on the legislative level. It was recognized that political system viability and legitimacy mostly depends on state institutions and highest rank officials, corresponds to values and ideals accepted in the society as much as their conduct is in accordance with the norms of social morality. Hence, Law "On Ethics Norms Reform" was adopted in November, 1989, having extended the provisions of the Law of Ethics for all branches of power - legislative, executive, judicial. Relatedly, "Principles of Ethical Conduct of State Officials and US Government Officials" was adopted by the US President's decree.

Some provisions of the Principles are as follows:

- state service is "social trust service" and requires from an official to place loyalty to the Constitution, laws and ethical principles higher than private interests;

- a state institution official shall not have financial interests which could thwart his/her duties fulfillment in good faith;

- he/she mustn't participate in financial operations using the information for internal use only which is forbidden to be disclosed or let that information be used in order to defend somebody's private interests;

- a state official doesn't have right to demand or accept any presents or other awards having cash value (except the cases stipulated by laws);

- he/she mustn't undertake unapproved duties and give promises which for see the liabilities for their fulfillment for government institution;

- he/she mustn't use offices in order to gain his/her own benefit;

-he/she is responsible for informing proper authorities on all facts as for wasteful spending, fraud, abuse and corruption in the state institution which he/she is aware of;

- he/she has to execute his/her responsibilities imposed on him/her as on a citizen of the country by law with due diligence, first of all, as the payment of federal and local taxes. 
Having analyzed the content of principal provisions "Principles of Ethics", we can make a conclusion that the main requirement for US state officials is considered to be proper management of his/her area of responsibility, faithfulness, liability to state and society. Although, the principles concerning state official's professionalism are not specified in the document.

Alongside with the adoption of "Principles of Ethics", special departments aiming to undertake control of ethic norms compliance were established. Thus, two associations are functioning in the USA - American Society of Public Administration (ASPA) and International City/County Management Association (ICMA). Those associations adopted codes of conduct, developed certain procedures in order to control the mechanisms of proper conduct sanctioning. Essential breaches of norms specified in those codes made by an ICMA member overtly or secretly are checked by the representatives of the Association; expulsion from ICMA is applied as sanctions. Dismemberment is considered to be the ultimate sanction for ASAP members as well.

In 1990 the executive order \# 12731 was signed by the US President. It confirmed earlier adopted acts which assisted to put in force "General Principles of Ethical Conduct for Government Members and State Officials" those were compulsory for all US executive power officials. [6].

Modern ethical system in the USA embraces society and all branches of power, i.e. in the USA the movement for moral power and moral society doesn't concern only state power but every citizen as well. It should be noted that the principles of freedom and justice are fully implemented in the ethical standards of for US state officials, that is an essencial conduct oriented to social values strengthening. State officials' ethical conduct is based on the set of rules morally outlined by currently accepted reality which constantly reminds us who we are, who we will become, who we can become [6].

Being effective from 1993 "Ethical Conduct Norms for Executive Branch of Power Officials" has currently become ones which are mostly well-known and quoted in the USA. Alongside with the standards of conduct for public officials, those norms contain other rules relating to public service ethics and essentially determine state authorities' self-will during working out the standards of conduct, namely: the methods of income declarations adoption; the rules concerning the abuse of authority, principles of functioning the ethics management in the government, etc.

Having investigated legal base for US state officials' ethical conduct, we can make a conclusion that there is a great number of acts, codes and ethical principles for officials in the USA, for this reason every branch of power has its own code of ethics and specially formed bodies which are to control the information collection and, if there any breaches are found out, their own punishment departments. At the same time, most governments of the states and local authorities obtain their own codes of public officials' ethical conduct which are under their jurisdiction.

Other countries followed the US example. In 1985 in Canada "Code of State Service Values and Ethics" was adopted containing the rules of conduct for all state officials without any exception. Integrated two-chapted document giving tips to all public service officials as for their duties and expected conduct as for values and ethics at their job place was made in Canada. To follow that Code is one of the conditions for employment.

Ethical Code and Canadian legislation set high ethical and professional demands for every state official and deputy.

"High competence, impartial and representative state service able to render services in two official languages where the position appointment is based on the principles of honesty, accessibility, representativeness and clarity" is a kind of strategic output which is a crucial goal of Canadian Commission in State Service Issues.

The Commissioner's Office in Ethics and Conflicts of Interests has been functioning in Canada since 2006. This parliamentary institution is independent from any political forces and deals with monitoring of Canadian lawmakers' conduct. The Commissioner's Office in Ethics and Conflicts of Interests usually starts detailed investigation of any case of deputy's inappropriate conduct after correspondent inquiry from parliamentary deputies or governmental institutions those could be negatively influenced by such conduct.

At the same time, Canadian Commission in State Service Issues provides high professional and political neutrality of Canadian public officials and, moreover, political and economic corruption inadmissibility. On the Canadian example, we can see how control and stimulation mechanisms enable to be helpful in order to form highly ethical and professional state service reforms but well-judged and agreed upon with the citizens and are considered to be the guarantee of country's successful development.

In the countries of the European Union, state officials' conduct standards are specified in the special acts which are generally called - Codes of Conduct for State Officials but they can have different titles depending on the country (for example, "Ethical Code", "Rules of Ethical Conduct", "Conduct Standards for State Officials", etc) [7].

Depending on the title Codes of Conduct contain legible and concise instructions as for what kind of conduct the organization expects from their members and what ideas it is going to achieve.

The goal of Code of Conduct for State Officials is threepronged:

1. To characterize ethical climate which prevails in State Service.

2. To form ethical conduct norms those are expected from the state officials.

3. To interpret to the public what kind of conduct should be expected from the state officials and how they should behave in the relationships with them. 
It is worth mentioning that in the Federal Republic of Germany professional state service appeared to be one of the first ones in Europe. Therewith, taking into consideration that Germany is the federal state and the power is distributed between the Federation and particular lands; state service system is divided into state federal service, service on the level of the lands, service on the level of the communities and local self-government service. State service on those three levels is governed by federal laws and on those three levels the integral ranking system is established; service integral rules, rights, duties, wage and pension system are functioning.

State service system is based on the principles of service devotion, legitimateness, integrity, professionalism and stability, which is regulated by a number of laws. But the FRG Constitution having been adopted on May 23, 1949 is considered to be the Principal Law of Germany and is of utmost importance for state service organization and functioning. (Grundgesetz für die Bundesrepublik Deutschland).

In the Article 33 of the Principal Law, it is stated as follows: "The power of public service shall consider traditional principles of professional bureaucracy". Furthermore, the state service equality principle is specified in the section 3 of that Article. In accordance with the Federal Law upon State Officials, "any state official doesn't serve to certain political party but to the nation" [8]. He/she is obliged to perform his/her duties "justly and impartially being applied by social interests".

Any state official should show his/her devotion to the principles of free democratic system [3].

FRG legislation foresees criminal liability for any wrong-doings those might be committed by state officials when their performing the employment duties. Officials take higher responsibilities for spying, breach of professional secrecy, bribery, criminal appropriation of corporate opportunities and are subjects to disciplinary actions having been performed at the service and out of it.

German state service system practice is turned out to be quite interesting and various, in the process of its development it has undergone different stages, although, at present, that is considered to be one of the most powerful bureaucratic systems in the world and is worth to be studied. In our opinion, it is important to introduce that practice to reform and improve state service of our country. Therefore, the principles of objectiveness, juistice and impartiality are applied to prepare and approve political and administrative solutions when any state official's professional position is independent of the influence of political or private interests, social interests' devotion, loyal conduct to the state and its legitimate political management in order to favor the making of professional and effective state service which is able to provide meaningful state authorities' functioning to support citizens' welfare and make administrative space of the European pattern.
In France the state official ethics means, first of all, respect to laws which is formed in the area of personnel management being considered in the juridical and disciplinary aspects. In French administration to manage the personnel signifies to use statutes i.e. to arrange contests, to prepare orders on position appointments, to approve personnel shake-ups, to introduce the staff; salary and fees cancellation as well.

Ethical rules of conduct for state officials are fixed in Law "On ethics, rights and duties for state officials" in France. That Law was adopted on April 20, 2016 in order to strengthen trust between French citizens and officials. Main principles of state officials' activities such as impartiality, fairness, honesty, citizen's respect to the law are established in that instrument. The first section of the Law contains the following provisions as for the state officials ethical conduct: - conflict of interests prevention (Articles 1-5); - a state official doesn't have to be involved in other activities (Article 7); - provisions as for Committee on State Service Ethics (Articles 8-9). Moreover, the mechanism of protection of those state officials who inform about corruption and conflicts of interests is specified in the Law "On ethics, rights and duties for state officials".

Current French state service modernization program is connected with the Prime Minister's Decree "On State Management System Upgrading" dated 1989, which determined following four modernization principles [9]:

- to restore social dialogue, first of all, with trade unions;

- to improve responsibility and strengthen state officials' reporting relationships;

- to introduce management assessment;

- to provide state service openness for citizens and improve relationships with consumers (quality of services, reducing lines in state establishments, advancing the level of citizens' information sharing, etc.).

Hence, the lack of realization terms in that circular note provisions caused its low effectiveness.

Considering the consequences of administrative reform "technocratic" model enforced to reconsider basics of French approach to the role of state, state service personnel problems, regulating state officials' conduct by means of ethics.

When making reforms France gives preferences to the programs which favored labor complex motivation and acceptance by personnel the essence of reforms.

Besides, social dialogue program (every worker's participation in defining labor conditions, administration and career promotion) and social partnership (improving relationships with the public) are taken into consideration.

The structure of principal ethical rules for French state officials is similar to the structures accepted in all democratic countries and include: commitments to abide by the law and instructions; impartiality; secrecy obligation; passiveness in social and political aspects; prohibition of other professional activities; loyalty, 
honesty. Mentioned above rules are considered to be the base of state officials' ethics [10].

Every country has its own mechanism of taking control of keeping appropriate level of state officials' ethics of conduct. Thus, in the UK being at present in the process of "brexit", Commission on State Service was created in accordance with the Royal decree in 1855 and is still functioning. Ethical control procedure in the British Parliament appeared more than fifty years ago. Every Chamber of the Parliament has its duty regulations "Standing Rules", which define ethical aspects of MPs' activities.

Nowadays, more than 400 rules embracing all sides of British parliamentary activities have been developed and are in force [11]. In the Chamber of Commons of the British Parliament there was the position of Authorized Representative in Conduct Standards in the British Parliament. Special Committee in Public Sphere Standards has been functioning since 1994. It was initiated to be formed basing on the results of public-opinion poll which revealed that for ten year period public assessment of the MPs has fallen by $20 \%$. Committee's powers and authority are quite wide. It is entitled to force an MP to apologize before the Chamber of Commons for the breach of ethical requirements or make recommendations to the Chamber of Commons to dismiss an MP from participation in the work of the Chamber [12].

European practice as for public service officials ethical conduct regulation revealed that the core idea of ethical management in Europe totally corresponds to the approach which is functioning in the USA. But that doesn't mean that ways of its realization are identical. British state service is defined by the researchers as one which is determined by high corporate ethics and strict correspondence of the Code to the administrative morality. It is regarded that in most EU countries the model code of conduct for public officials where conduct standards and criteria for state officials are employed.

Conclusions. In the conditions of Ukrainian presentday development it is difficult to predict which one of the models having been implemented into state management practice of foreign countries could be effective and fully correspond to the problems and demands of domestic state formation. Therefore, an attempt to realize one of the state management western concepts will not be quite effective in Ukraine viewing Ukrainian state management theories and practice. Applying the best experience of foreign countries under investigation, Ukraine shall build its own way of development.

Developing concepts and strategies of Ukrainian development, the state has to involve representatives of all social groups, consider the interests of all parties concerned and work on the principles of cooperation, partnership and compromise which became foundation for political and economic dialogue in the framework of inner and external relationships of developed countries.

Given above analysis clearly shows that, certainly, there is a necessity to make a specific legislative instrument in Ukraine which could regulate state officials' ethical conduct and become foundation for correspondent ethical organizational environment.

Ukrainian policy as for European system of values obligates to put into practice qualitatively new state management standards, basing on the experience of EU developed countries. Specially valuable thing is considered to be the experience of the countries which have managed to have been included to the twenty least corrupted countries and have succeeded in the moral relationships management in state service of their countries [2].

As an example the experience of the countries which shows how with the help of effective control to improve the level of ethical attitude to the citizens could be employed. We consider that officials, scholars and representatives of non-governmental organizations should be involved to develop the specific legislative instrument devoted to the issues of state officials' ethics.

It is important to establish inner procedures of control over fulfilment of professional and ethical demands and conditions. The goal of such structure should be control which could hold officials back from the actions those could show their dishonesty when they are performing assigned tasks, communicating with citizens and making decisions. Requirements to the state officials as for their relationships with citizens should be standards of their conduct and estimated by the public, be foundation for defining the effectiveness of managerial activities.

Thus, the world practice shows that state service ethization enables to humanize social relationships, significantly improve effectiveness of state bodies activities and is considered to be essential for Ukraine under current conditions.

The perspective for the further research is to define directions of national legislation adaptation to the state standards and stages of state governing reforms.

\section{References:}

1. Shuvalova, N. N. (2016). Etyka y etyket ghosudarstvennoj y munycypaljnoj sluzhbi. Moskva : Jurajt.

2. Rudakevych, M. I. (2007). Profesijna etyka derzhavnykh sluzhbovciv: teorija i praktyka formuvannja v umovakh demokratyzaciji derzhavnogho upravlinnja. Ternopilj : Vydavnyctvo Aston.

3. Pravyla etychnoji povedinky derzhavnykh sluzhbovciv (dosvid krajin Jevropejsjkogho Sojuzu ta SShA). Retrieved from: http://euinfocenter.rada.gov.ua/uploads/documents/29069.pdf

4. Shuvalova, N. N. (2013). Upravlenye nravstvennimy otnoshenyjamy v systeme ghosudarstvennoj sluzhbi: oryentacyja na uspekh. Pravo y upravlenye, XXI vek, 41-48.

5. Vasylevsjka, T. E. (2013). Etyka derzhavnykh sluzhbovciv i zapobighannja konfliktu interesiv. K. NADU.

6. Obolensjkyj, O. Ju. (2003). Derzhavna sluzhba. K.: KNEU. 
Електронне наукове фахове видання з економічних наук “Modern Economics», №2 1 (2020), 108-114 https://modecon.mnau.edu.ua | ISSN 2521-6392

7. Systema derzhavnogho upravlinnja Kanady: dosvid dlja Ukrajiny / uklad. O. I. Maksymova ; za zagh. red. Ju. V. Kovbasjuka. K. : NADU, 2010.

8. Bundesbeamtengesetz. Retrieved from: https://dejure.org/gesetze/BBG.

9. Vasylevsjka, T. E., Salamatov, V. O., Marushevsjkyj, Gh. B. (2015). Etyka derzhavnogho upravlinnja. K. : NADU.

10. Loi relative à la déontologie et aux droits et obligations des fonctionnaires. Retrieved from: http://www.senat.fr/dossierlegislatif/pjl15-041.html.

11. Kovalenko, V. L. (1999). Pravove reghuljuvannja povedinky derzhavnykh sluzhbovciv: novi tendenciji. Derzhavna sluzhba $v$ Ukrajini: orghanizacijno-pravovi osnovy i shljakhy rozvytku. Kiev, 155-181.

12. Vasylevsjka, T. V. (2008). Osobystisni vymiry etyky derzhavnogho sluzhbovcja. Kiev: NADU. 